\title{
TOURISM CLIMATE COMFORT INDEX (TCCI) - AN ATTEMPT TO EVALUATE THE CLIMATE COMFORT FOR TOURISM PURPOSES: THE EXAMPLE OF SERBIA
}

\author{
ANĐELKOVIĆ G. \\ PAVLOVIĆ S. \\ ĐURĐIĆ S. \\ BELIJ M.* \\ STOJKOVIĆ S.
}

\author{
University of Belgrade - Faculty of Geography \\ Studentski trg 3/III, 11000 Belgrade, Serbia
}

Received: $16 / 10 / 2015$

Accepted: $17 / 02 / 2016$

Available online: 23/05/2016 *to whom all correspondence should be addressed: e-mail: marija.belij@gmail.com

\section{ABSTRACT}

This paper proposes one new attempt to formulate a mathematical approach to climate parameters in the context of their complex implications for tourist activities through the tourism climate comfort index (TCCI). This paper also aims to formulate an original and optimal mathematical correlation between readily obtainable climate parameters (mean monthly air temperature, monthly amplitude of air temperatures, monthly insolation, average monthly relative air humidity and the number of rainy days), which results in values of the TCCI. Simultaneously, this index will provide the values correspondent to the values of air temperatures $\left({ }^{\circ} \mathrm{C}\right)$, which represents a comparative baseline understandable equally for tourists, tourism planners and managers. The example of Serbia as a mainland country in the south-east of Europe was used to apply the proposed methodology. The spatial-temporal variability of TCCl is formulated on basis of data for the period 1961-2000 while for testing model was used selected period 2001-2010 on the sample of 26 meteorological stations distributed all around Serbia. For this purpose a standard statistical techniques were applied and ArcGIS software was used for analyze of the variability of the TCCl in relation to the altitude, which is of particular importance for the development of tourism in the mountains. Checking variability of the index was carried out in relation to statistical data about number of tourists on the three most visited tourist destinations which are of importance for the development of urban, mountain and spa tourism, the leading forms of tourism activities on the territory of Serbia. The obtained results correspond with the fact of the pronounced seasonality of tourism market and thus may represent a good basis for future tourism planning and management.

Keywords: climate index, meteorological stations, Serbia, temperature, tourism

\section{Introduction}

Human perception of climate is closely related to the activities such as tourism. The knowledge of climate parameters and thresholds and their appropriateness for tourism and recreation are basic information about several possibilities for touristic activities and recreation (Matzarakis et al., 2014). However, the condition of a single climate parameter cannot fully characterise the climate conditions in tourist destinations. According to De Freitas, (2003), and Vitt et al., (2015), climatic variables can be analysed by way of three aspects according to aesthetic, physical and thermal facets.

Depending on the regional climate differences between the tourists' places of residence and holiday destinations, it is possible to identify diverse approaches to the notion of climate comfort. Good climatic 
and bioclimatic conditions are crucial issues for competitiveness as climate is important for travel apart from costs, destination's natural resource base and attractions (Matzarakis and Nastos, 2011). Bigano et al., (2006) drew our attention to a possibility of asymmetry in climate preferences between different countries depending on climate conditions in the home area of residents. Accordingly, individuals from colder climate conditions can be less demanding in view of temperature than those coming from warmer climates.

Eugenio-Martin and Campos-Soria, (2010), estimated the influence of climate as travel determinants in relation to various tourism activities. The criteria such as temperature, precipitation, sunshine and wind are significant for coastal destinations, but less significant if tourists are interested in sightseeing cities and in cultural heritage (Gómez Martín, 2005; Morgan et al., 2000).

In one of the studies of the relationship between climate and tourism, Besancenot (1989) argued that ideal climate for tourism should provide basic levels of comfort, enjoyment and safety. However, the perceptions of "good" and "bad" weather are subjective and they depend on a range of factors (Jacobsen et al., 2011; Meze-Hausken, 2007; 2008;), thus comfort, discomfort, satisfaction, safety are the reasons for making decisions about destinations and activities of tour operators (Førland et al., 2013).

As De Freitas (2003) indicates, tourists respond to integrated effects of climate (e.g. temperature, humidity, wind, precipitation, insolation). A climate index is one of the ways the researchers have been using to present a manifold nature of climate resources for tourism. Several indices have been developed in the last thirty years for evaluating the appropriateness of climate for tourism activities (Mieczkowski, 1985; Becker, 1998 2000; Morgan et al., 2000; Goh, 2012; Tang, 2013; Olya and Alipour, 2015a). Tourists and tour operators can use the index to choose the best time and place for holiday and travel and to plan activities suitable to the forecast weather (Eugenio-Martin and Campos-Soria, 2010). Such information has marketing implications for travel agencies (Olya and Alipour, 2015b).

De Freitas (1990) proposed a model of the ideal tourism climate index that should rely on the standard climate data, minimise the average, give preference to the actual parameters, take into account as many environment parameters as possible, integrate the effects of thermal components, as well as on thermophysiological variables that are used for obtaining thermal comfort or discomfort levels. It is supposed to include all three facets of climate considered relevant for tourism - thermal, aesthetic and physical-mechanical, and to acknowledge climate as a limiting factor for tourism (Moreno et al., 2008).

The climate indices relevant to tourism can be grouped into three categories. The basic indices are synthetic values whose thermophysiological relevance has generally not been proven. Bioclimatic and combined tourism climate indices have more than one climate parameter, so their combined effects are taken into consideration (Mieczkowski, 1985).

One of the several quantified benefits of climate is widely accepted Mieczkowski's (1985) tourism climate index (TCl), which summarises and combines seven climate variables, three of which are independent, and two of which are combined with bioclimatic ones. To calculate the index, seven monthly parameters are used (maximum daily air temperature, mean daily air temperature, minimum daily relative humidity, average daily relative humidity, amount of precipitation, daily insolation and average wind speed). The research carried out by Scott et al., (2008) presents optimal climate conditions and relative significance of four climate parameters (temperature, precipitation, insolation and wind) in three tourist areas (coastal, city and mountains). Different climate preferences suggest that the universal tourism climate index, originally made by Mieczkowski (1985), can be conceptually illogical. Instead, more attention should be paid to further studies to develop tourism climate indices for specific tourism segments, especially for those heavily weather-related ones (Scott et al., 2007). A new generation of climate tourism indices has been introduced to mend the flaws of the existing ones, by way of formulating an index that will integrate the effects (De Freitas et al., 2008).

This paper has been based on the assumption that temperature is the key climate parameter for human comfort and that its flow combined with the effects of other parameters enables the body not to be exposed to continuous overheating or cooling. This study aims to formulate an original and optimal mathematical correlation between readily obtainable climate parameters (mean monthly air 
temperature, monthly amplitude of air temperatures, monthly insolation, average monthly relative air humidity and the number of rainy days), which results in values of the tourism climate comfort index (TCCI). Simultaneously, this index will provide the values correspondent to the values of air temperatures (in ${ }^{\circ} \mathrm{C}$ ), which represents a comparative baseline understandable to a large number of users. The index calculated this way can objectively bring climate conditions and tourists' preferences for particular tourist destinations into a cause and effect relationship, with an option of comparability according to different times and locations.

\section{Material and methods}

For the purpose of determining $\mathrm{TCCl}$, an example of a mainland country in the south-east of Europe has been chosen. Serbia is located in the central part of the Balkan Peninsula between $41^{\circ} 53^{\prime} \mathrm{N}$ and $46^{\circ} 11^{\prime} \mathrm{N}$ and $18^{\circ} 49^{\prime} \mathrm{E}$ and $23^{\circ} 00^{\prime} \mathrm{E}$ and its territory covers $88,361 \mathrm{~km}^{2}$ (Figure 1). The northern part of Serbia, the Pannonian Plain and its rims, is mostly lowland, whereas the central and southern parts are hilly and mountainous. Serbia lies only a few hundred kilometres northeast of the Adriatic Sea, but it is separated from it by high mountains, some of which exceed 2,000 metres. Therefore, the climate of Serbia is temperate continental, with more or less distinct local characteristics and gradual change of seasons, with warm summers of even over $30^{\circ} \mathrm{C}$ and snowy winters with temperatures even below $-10^{\circ} \mathrm{C}$.

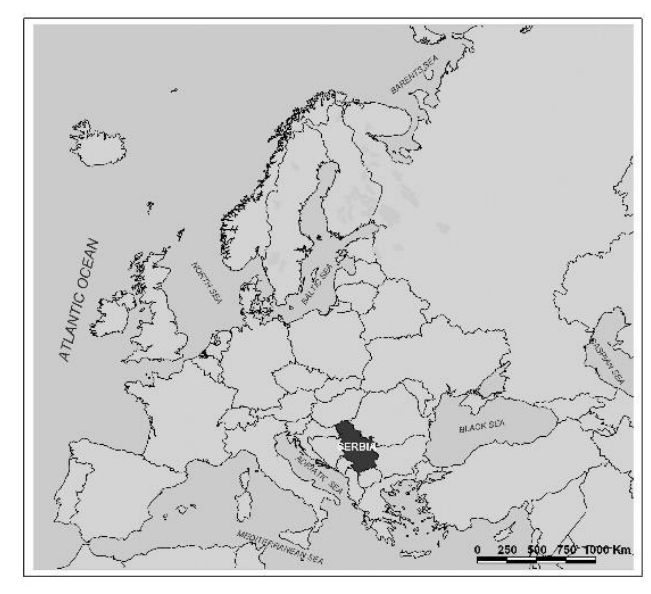

Figure 1. Geographic location of Serbia on the political map of Europe

Zonal air currents prevail above the territory of Serbia and in winter they have well-defined waves with frequent and intense breakthroughs of cold air masses from the north, but in summer, they are twice weaker, and purely zonal, in the west-east direction. The highest activity of depressions occurs in the Pannonian Plain. Large mountain complexes of the Alps and Carpathians extensively change the atmospheric circulation whereas the landscape of Serbia affects the circulation systems in smaller proportions. Consequently, there are specific air currents with zones of delay, draft, lee waves etc.

The methodology of statistical analysis of climate parameters values for the normal climate period of 1961-2000 has been applied to calculate the tourism climate comfort index. The obtained results were compared with the series for the last decade (2001-2010) in order to determine variability of the index. The indices for meteorological stations in Serbia have been calculated, except for the stations in the territory of Kosovo, whose official data was unavailable. The tourism climate comfort index has been analysed for 26 meteorological stations (http://www.hidmet.gov.rs) that cover the territory of 77,474 $\mathrm{km}^{2}$, which amounts to $87.7 \%$ of total area of Serbia. The stations are equally distributed and each of them covers $3,000 \mathrm{~km}^{2}$ of the surrounding territory. To check the validity of the results obtained by calculating the $\mathrm{TCCl}$ index, the statistical data on tourist visitation was used (data on monthly visitation values for the period of 2001-2010). Spa and mountain tourism are, apart from the city tourism, the leading forms of tourist activity in a mainland country of the south-east Europe, such as Serbia. 
The tourism climate comfort index (TCCI) is an attempt to satisfy the criteria in order to calculate the values relevant to a large number of users, and especially to tourism promotion, on basis of readily available parameters. According to the following formula, it is evident that a value of one quantity is expressed in absolute values comparable with the quantities empirically known to a large number of users, such as air temperature. It is calculated according to the formula:

$\mathrm{TCCl}=\mathrm{T}_{\mathrm{m}}+0.5 \mathrm{~A}_{\mathrm{Tm}}+0.1\left(\mathrm{~S}_{\mathrm{m}}-\mathrm{U}_{\mathrm{m}}\right)-\mathrm{n}_{\mathrm{rd}}$

where $T_{m}$ - mean monthly air temperature $\left({ }^{\circ} \mathrm{C}\right), A_{T m}$ - monthly amplitude of air temperature $\left({ }^{\circ} \mathrm{C}\right), S_{m}-$ monthly insolation or duration of sunshine (hours), $U_{m}$ - average monthly air humidity (\%) and $n_{r d}-$ number of rainy days in a given month.

The index indicates the climate comfort for tourism trends: its positive value demonstrates the climate benefits, and the larger it is the more attractive climate is in terms of tourism; if the index is negative in a month that means that month is not favourable for tourism activities.

The formula sums up the elements that have positive effects on man and tourism trends and subtracts the elements with negative effects. In order to reduce the final result to the level comparable with the air temperature value, the sum of monthly insolation and monthly air humidity has been divided by ten. Bearing in mind the set hypothesis and the aim of the paper, the results of this index calculation should be indicative and correspondent to the indicators of tourism visitation.

Linear regression by Matlab R2013a software was used to validate obtained results, i.e. to demonstrate the relation between $\mathrm{TCCl}$ and the number of tourists in the major tourist destinations in Serbia (Beograd, Zlatibor and Vrnjačka Banja). Also, the appropriate spatial-temporal analysis of the TCCI was performed using geo-statistical techniques (e.g. CoKriging) using ArcGIS software.

\section{Results and discussion}

On basis of the calculated values of the climate index, a scale of climate comfort has been formed, which considerably coincides with the sensation of comfort under the influence of air temperature. Thermal comfort is present when the body temperature is within the specific narrow borders that we acknowledge as satisfaction with thermal environment. Although the regional climate conditions, living conditions and cultures extremely vary in the world, people prefer thermal comfort choice under the same conditions of clothing, activities, humidity and wind speed. Although, Mieczkowski (1985) and De Freitas et al. (2008) defined well known scales of $\mathrm{TCl}$ and Climate Index for Tourism (CIT), on basis of the usual empirical experiences for the residents of temperate climate regions and according to our proposed formula (1), we suggest a scale for evaluating the climate comfort index as presented in Table 1.

Table 1. Scale of tourist climate comfort index

\begin{tabular}{|c|c|c|c|}
\hline Value of index & Rating & Description & Purpose \\
\hline below 0 & VERY UNFAVOURABLE & $\begin{array}{l}\text { unpleasant and } \\
\text { unfavourable }\end{array}$ & "snow" activities \\
\hline $0-20$ & UNFAVOURABLE & $\begin{array}{l}\text { partly pleasant and } \\
\text { favourable }\end{array}$ & Excursions \\
\hline $20-30$ & $\begin{array}{c}\text { FAVOURABLE } \\
\text { (between } 24 \text { and } 28 \\
\text { VERY FAVOURABLE) }\end{array}$ & $\begin{array}{l}\text { pleasant and } \\
\text { favourable }\end{array}$ & $\begin{array}{c}\text { all tourism activities } \\
\text { (except snow and extreme } \\
\text { activities) }\end{array}$ \\
\hline $30-40$ & UNFAVOURABLE & $\begin{array}{l}\text { partly pleasant and } \\
\text { favourable }\end{array}$ & $\begin{array}{c}\text { recreational water activities } \\
\text { (coastal, lakeside, } \\
\text { spa tourism) }\end{array}$ \\
\hline over 40 & VERY UNFAVOURABLE & $\begin{array}{l}\text { unpleasant and } \\
\text { unfavourable }\end{array}$ & $\begin{array}{l}\text { sunbathing, bathing } \\
\text { (coastal tourism) }\end{array}$ \\
\hline
\end{tabular}


Although the entire territory of Serbia is relatively small, it is easy to perceive the distribution patterns of $\mathrm{TCCl}$ caused by the factors of the geographic position, landscape (altitude in particular) and urban effects. The tourism climate comfort index has a negative value at almost all lowland stations for four months: between November and February (Table 2 and 3). For the larger part of the country, May, June and September are characterised by the index between 20 and 30, which represents the value of optimal comfort for people and tourism activities. At altitudes above 1,000 metres, the index is over 20 during July and August, making the mountains a favourable resort for those looking for optimal climate conditions.

Table 2. Tourism climate comfort index in meteorological stations in Serbia according to climate data for the period 1961-2000

\begin{tabular}{|c|c|c|c|c|c|c|c|c|c|c|c|c|c|}
\hline Meteorological station & asl (m) & Jan & Feb & Mar & Apr & May & Jun & Jul & Aug & Sep & Oct & Nov & Dec \\
\hline Palić & 102 & -11.01 & -3.98 & 7.24 & 16.36 & 26.71 & 31.98 & 39.89 & 38.50 & 27.60 & 17.47 & -2.88 & -12.78 \\
\hline Sombor & 88 & -9.81 & -3.34 & 8.06 & 5.96 & 26.16 & 31.11 & 39.12 & 37.50 & 26.52 & & -3.55 & -11.68 \\
\hline Novi Sad & 84 & -10.52 & -3.66 & 7.91 & 5.70 & 26.46 & 31.46 & 39.67 & 38.97 & 27.81 & & -2.18 & -11.54 \\
\hline Kikinda & 81 & -11.11 & -4.08 & 8.19 & 16.73 & 27.79 & 32.64 & 41.54 & 39.16 & 28.99 & & -2.94 & -12.67 \\
\hline Zrenjanin & 80 & -10.40 & -3.17 & 8.21 & 15.76 & 26.84 & 31.10 & 39.23 & 38.65 & 28.24 & 18.37 & -1.89 & -11.86 \\
\hline Sremska Mitrovica & 82 & -11.22 & -3.57 & 7.76 & 14.91 & 25.46 & 30.24 & 38.46 & 37.13 & 26.22 & 16.76 & -3.07 & -11.70 \\
\hline & 132 & -9.92 & -3.26 & 8.38 & 6.02 & 25.42 & 30.70 & 39.52 & 38.64 & 27.61 & & -0.72 & -10.52 \\
\hline & 121 & -11.55 & -4.28 & 5.43 & 13.57 & & 27.74 & 38.40 & 36.38 & & & -3.39 & -12.05 \\
\hline vo & 176 & -10.09 & -3.86 & 6.01 & 3.31 & 22.59 & 27.54 & 37.61 & 36.14 & 26.42 & & -0.62 & -10.33 \\
\hline evac & 185 & -7.84 & -2.11 & 8.16 & 15.50 & 24.91 & 30.24 & 39.80 & 38.25 & 28.31 & 17.09 & 1.28 & -9.17 \\
\hline Požega & 310 & -16.73 & -8.30 & 2.40 & 11.28 & 17.54 & 20.88 & 30.13 & 29.37 & 17.51 & 6.20 & -7.18 & -17.68 \\
\hline & 121 & -9.67 & -2.97 & 7.92 & 16.06 & 25 & 30.85 & 39.99 & 39.44 & 28.44 & 17 & -0.17 & -11.21 \\
\hline Velik & 82 & -11.72 & -5.54 & 6.99 & 14.75 & 24.60 & 29.52 & 38.20 & 38.36 & 27.99 & & -2.01 & -13.82 \\
\hline /rh & 1037 & -15.29 & -11.56 & -4.66 & 5.76 & 16.84 & 24.86 & 33.74 & 34.35 & 21.82 & 8.56 & -7.35 & -17.25 \\
\hline & & & & 5.78 & & & & & 42. & & 15.82 & -2.45 & -9.99 \\
\hline bor & 1028 & -14.06 & -10.46 & -3.37 & 3.86 & 12.91 & 18.22 & 28.44 & 28.17 & 18.95 & 9.72 & -4.65 & -14.75 \\
\hline Sjenica & 1038 & -13.37 & -8.71 & 0.19 & 6.65 & 15.40 & 20.55 & 29.52 & 28.49 & 18.84 & 10.09 & -3.65 & -14.15 \\
\hline & & -12.36 & -4.50 & 5.92 & 13.96 & 21.41 & 26.42 & 35.50 & 35.70 & 25.37 & 15.05 & -2.23 & -13.15 \\
\hline nik & 1710 & -12.84 & -11.54 & -8.81 & -2.79 & 6.75 & 14.76 & 25.11 & 23.88 & 14.48 & 8.22 & -5.47 & -15.17 \\
\hline & & -11.87 & -5.01 & 6.54 & 15.01 & 24.38 & 30.66 & 40.19 & 39.94 & 28.58 & 16.95 & -1.37 & -13.39 \\
\hline Kruševac & 166 & -12.25 & -5.07 & 5.10 & 13.20 & 22.81 & 26.97 & 36.06 & 36.15 & 25.78 & 14.83 & -0.97 & -14.00 \\
\hline & 202 & -10.85 & -3.94 & 7.18 & 15.18 & 24.69 & 31.67 & 42.01 & 41.74 & 29.97 & 17.96 & -0.09 & -12.09 \\
\hline & & -8.58 & -4.55 & 5.10 & 15.88 & 25.55 & 33.00 & 42.57 & 41.80 & 30.11 & & -1.95 & -10.08 \\
\hline Dimitrovgrad & 450 & -10.11 & -4.63 & 5.19 & 12.88 & 22.76 & 28.90 & 40.27 & 40.41 & 30.14 & 17.68 & 0.15 & -11.04 \\
\hline Leskovac & 230 & -10.91 & -3.56 & 6.95 & 14.19 & 24.20 & 30.62 & 41.27 & 41.31 & & 16.99 & -0.19 & -12.53 \\
\hline Vranje & 432 & -11.52 & -4.49 & 6.44 & 14.39 & 23.29 & 32.44 & 44.12 & 43.32 & 31.00 & 18.05 & -1.21 & -12.83 \\
\hline
\end{tabular}

General "remaining" of the stations in the same categories of comfort shows that the conditions for tourism travel have not significantly changed. However, moving of the index into the category over 40 in almost all lowland stations is noticeable and significant for man's sensations, as it was in those categories only in the stations in the south-east of Serbia. From the aspect of comfort, that is the most significant change, at the expense of tourism trends and in the direction of summer conditions impairment.

It is necessary to pay attention to the index between 24 and 28 or to extremely favourable conditions in the recent period. There are 5 stations during May and as many as 7 stations during September in that zone. If compared to the previous period, it points to a significant impairment of conditions during May and sligthly impairment during September in the entire territory of Serbia.

As regards to mountains touristic resorts, Kopaonik (1710 m), Zlatibor (1028 m) and Crni Vrh (1037 m), the conditions for summer tourism belong to partly pleasant and favourable because values of TCCI exceeded 30 . 
Table 3. Tourism climate comfort index at meteorological stations in Serbia according to climate data for the period 2001-2010

\begin{tabular}{|c|c|c|c|c|c|c|c|c|c|c|c|c|c|}
\hline Meteorological station & $\begin{array}{l}\text { asl } \\
\text { (m) }\end{array}$ & Jan & Feb & Mar & Apr & May & Jun & Jul & Aug & Sep & Oct & Nov & Dec \\
\hline Palić & 102 & -10.03 & -3.08 & 9.40 & 22.73 & 32.40 & 37.63 & 43.79 & 42.33 & 24.62 & 16.63 & 1.76 & -13.26 \\
\hline Sombor & 88 & -9.92 & -1.72 & 9.40 & 22.65 & 33.69 & 37.46 & 43.58 & 41.75 & 24.17 & 17.16 & 0.94 & -13.61 \\
\hline Novi Sad & 84 & -10.60 & -2.49 & 9.96 & 20.86 & 32.34 & 37.32 & 44.62 & 42.60 & 23.33 & 16.11 & 3 & -12.78 \\
\hline Kikinda & 81 & -10.34 & -4.24 & 8.71 & 22.98 & 34.42 & 38.57 & 45.65 & 43.62 & 23.96 & 16.13 & 3.16 & -13.69 \\
\hline Zrenjanin & 80 & -10.07 & -2.71 & 9.86 & 23.32 & 33.00 & 37.34 & 44.72 & 43.12 & 24.16 & 17.10 & 4.24 & -11.90 \\
\hline Sremska Mitrovica & 82 & -12.31 & -3.82 & 8.84 & 20.36 & 31.40 & 34.68 & 42.39 & 40.15 & 21.73 & 14.51 & 1.93 & -13.96 \\
\hline & 132 & -9.88 & -2.71 & 10.54 & 19.89 & & & 42.95 & 40.90 & .07 & & 5.60 & .97 \\
\hline Loznica & 121 & -11.65 & -5.18 & 7.32 & 16.75 & 27.08 & 32.48 & 40.86 & 39.30 & 20.82 & 12.91 & 2.14 & -14.76 \\
\hline Valje & 176 & -10.58 & -4.72 & 7.52 & 16.76 & 27.21 & 31.90 & 40.80 & 38.84 & 19.82 & 12.74 & 3.86 & -12.81 \\
\hline Kragujevac & 185 & -9.03 & -4.77 & 9.79 & 18.69 & 29.20 & 36.08 & 43.05 & 42.00 & 22.31 & 13.52 & 5.43 & -9.78 \\
\hline & 310 & -14.46 & -8.96 & 4.17 & 11.69 & 14 & 26.10 & 32.49 & 32.26 & 14.39 & 5.12 & -4.27 & -16.12 \\
\hline Smederevsk & 121 & -9.19 & -3.21 & 10.00 & & 31.30 & 35.59 & 44.10 & 42.73 & 23.84 & 14.71 & 5.69 & -12.38 \\
\hline Velik & 82 & -11.28 & -4.56 & 7.60 & 19.20 & 29.81 & 35.60 & 43.28 & 42.64 & 22.92 & 14.72 & 2.62 & -11.79 \\
\hline Crni Vrh & 1037 & -19.85 & -14.02 & -4.26 & 6.66 & 17.47 & 25.86 & 33.88 & 31.10 & 12.07 & 0.00 & -9.32 & -19.26 \\
\hline Negotin & 42 & -8.13 & 0.14 & 12.68 & 20.10 & 34.29 & 43.47 & 49.55 & 45.76 & 26.64 & 12.00 & -1.48 & -10.91 \\
\hline Zla & 1028 & -13.90 & -11.80 & -0.48 & 6.14 & 17.87 & 24.26 & 31.66 & 31.49 & 12.56 & 7.82 & -0.32 & -17.11 \\
\hline & 1038 & -13 & -11.57 & 0.09 & & & 23.76 & 29.76 & 30.45 & 9.36 & 4.30 & -1.58 & -15.84 \\
\hline & 215 & -10.52 & -6.18 & 7.35 & 15.51 & 25.32 & 32.32 & 39.18 & 39.48 & 19.53 & 11.42 & 3.31 & -11.99 \\
\hline Kopaonik & 1710 & -18.68 & $-20.07-$ & -10.44 & -1.08 & 9.07 & 16.11 & 24.60 & 26.01 & 7.01 & 2.10 & -4.94 & -17.93 \\
\hline Ćuprija & 123 & -12.53 & -6.26 & 7.91 & 16.91 & 29.60 & 35.59 & 42.73 & 41.43 & 22.93 & 12.91 & 2.89 & -14.39 \\
\hline Kruševac & 166 & -10.61 & -5.73 & 7.30 & 15.30 & 27.73 & 35.12 & 40.59 & 37.25 & 22.77 & 13.46 & 3.24 & -12.39 \\
\hline Niš & 202 & -9.99 & -4.48 & 9.91 & 18.31 & 29.51 & 37.30 & 43.11 & 42.49 & 25.15 & 15.18 & 3.21 & -11.91 \\
\hline & 144 & -9.09 & -1.82 & 9.24 & 16.35 & 30.31 & 38.72 & 45.28 & 47.60 & 22.04 & 9.08 & -0.30 & -10.99 \\
\hline Dimitrovgrad & 450 & -9.09 & -5.40 & 7.75 & 12.82 & 25.14 & 33.31 & 41.32 & 38.60 & 23.23 & 12.82 & 2.66 & -11.13 \\
\hline Leskovac & 230 & -10.05 & -5.16 & 8.56 & 17.23 & 28.97 & 37.50 & 45.75 & 44.87 & 23.50 & 13.33 & 2.59 & -12.54 \\
\hline Vranje & 432 & -8.66 & -2.01 & 7.48 & 17.51 & 29.78 & 38.66 & 47.53 & 44.78 & 25.82 & 14.88 & 1.76 & -12.95 \\
\hline
\end{tabular}

On the examples of Beograd as the city with the largest population (1.6 million inhabitants), Zlatibor as a typical mountain resort, and Vrnjačka Banja as most visited spa in Serbia we can single out three "points" of specific climate conditions with important relevance for tourism. The analysed TCCl values are linearly mismatched, but their annual flow is parallel (Figure 2).
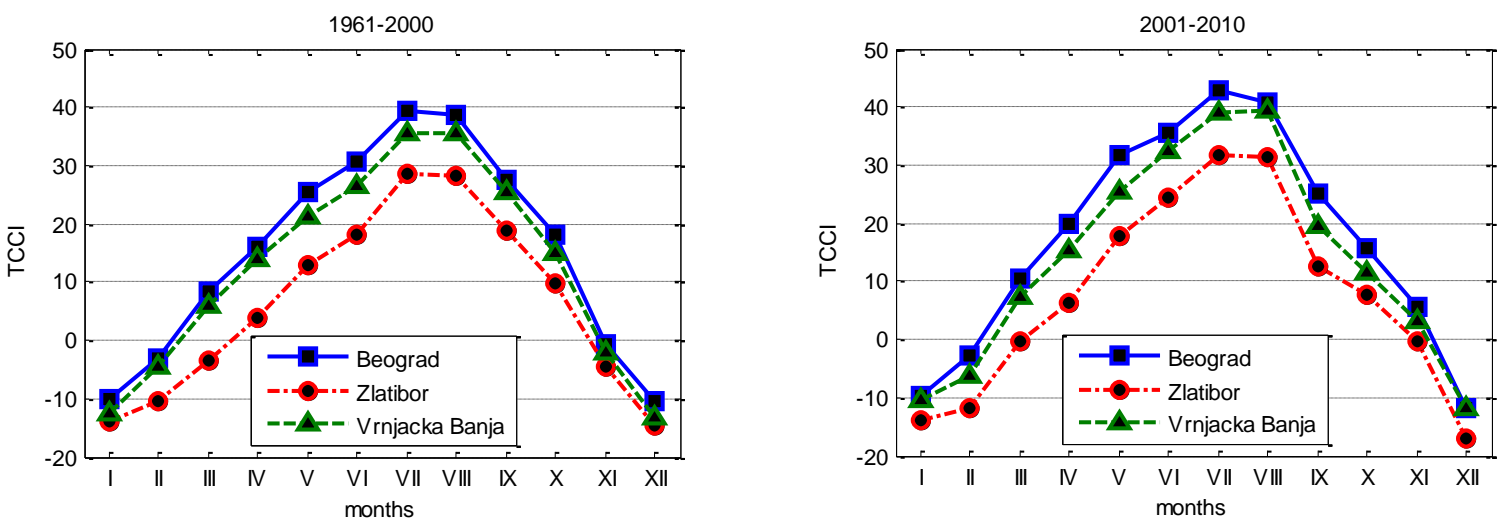

Figure 2. Annual flow of TCCl at three specific meteorological stations, examples of Beograd (132 m), Zlatibor (1028 m) and Vrnjačka Banja (230 m)

According to the spatial-temporal analysis was obtained that 15 stations during May, 5 stations during June and 10 stations during September have the index between 24 and 28 or extremely pleasant 
conditions. That means that May is extremely pleasant for tourism activities in Serbia, June and September just at particular sites and in July and August at mountains. It is interesting that September occurs in the zone of extremely favourable climate and tourism conditions only in combination with another month, whether May or June. Therefore, we could consider September's maximum of comfort as secondary. As far as mountains are concerned, it is extremely pleasant only at Kopaonik in July and August, which clearly depicts the conditions for summer tourism in those mountains.

Extreme index values at analyzed territory are not of significance unless they imply moving to another group of comfort, but they should nevertheless be mentioned. The differences between those values are not so distinct at low and high stations, but a slight influence of altitude can be noted.
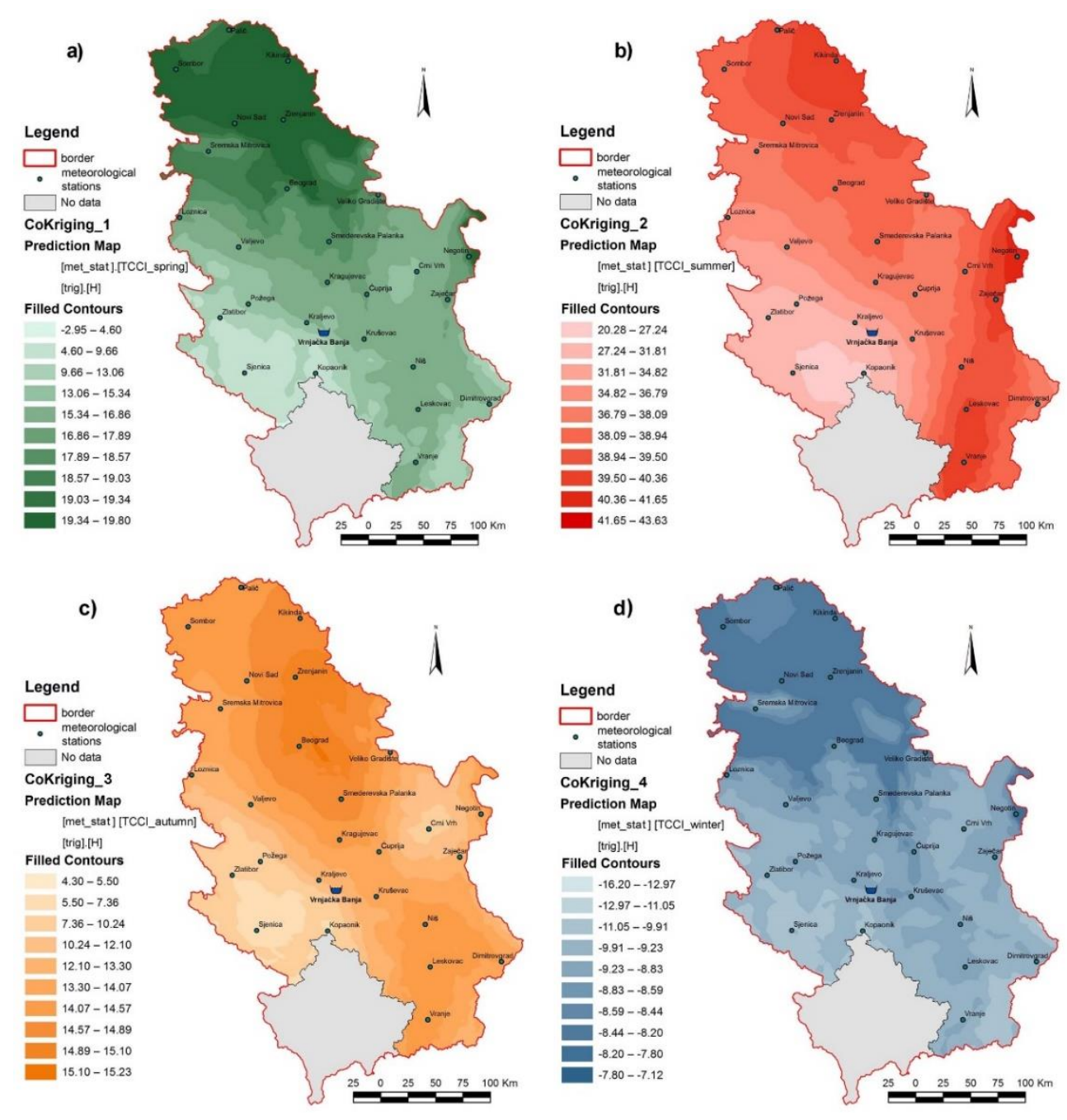

Figure 3. Seasonal distribution of $\mathrm{TCCl}$ according to altitude - a) spring, b) summer, c) autumn, d) winter

As Rosselló - Nadal (2014) stated, one of the main goals of climate indexes is to seek simplicity in analyses of seasonal patterns, it is performed the prediction of TCCI values for periode 1961-2010 per four seasones. Geostatistical method CoKriging by ArcGIS software was used to create output surfaces (Figure 3). According to the aim of interpolation it was used two datasets, seasonal average values of TCCI for analysed period and altitude data for more than 45,000 trigonometric points of Serbia. As we can see on Figure 3 it is obvious that strong regular relation between $\mathrm{TCCl}$ and altitude exists. CoKriging method was also used for calculation of TCCI values on the example of Vrnjačka Banja ( $230 \mathrm{~m}$ ) the most famous and visited spa in Serbia. The results obtained by interpolation correspond with results for the nearest meteorological station Kraljevo. 


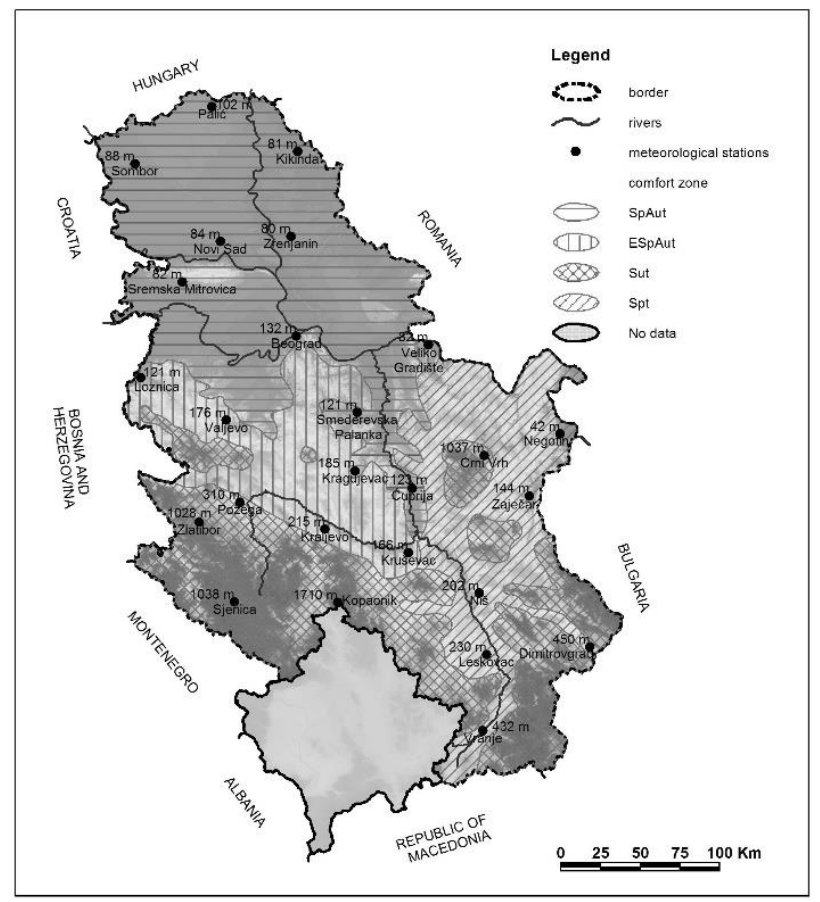

Figure 4. Geographic distribution of climate comfort zones in Serbia

A detailed analysis indicates that the tourism climate comfort index displays a very regular geographic distribution (Figure 4). An increase of very unfavourable and a decrease of very favourable monthly conditions are particularly indicative in the south of Serbia. According to the annual index flow, we can distinguish four types of annual distribution of comfort zone in Serbia (Figure 5), with monthly values regularly decreasing from north to south:

1. spring-autumn type (SpAut): maximum of comfort in May and September,

2. extended spring-autumn type (ESpAut): maximum of comfort in June and September,

3. summer type (Sut): maximum of comfort in July and August and

4. spring type (Spt): maximum of comfort only in May or in June.

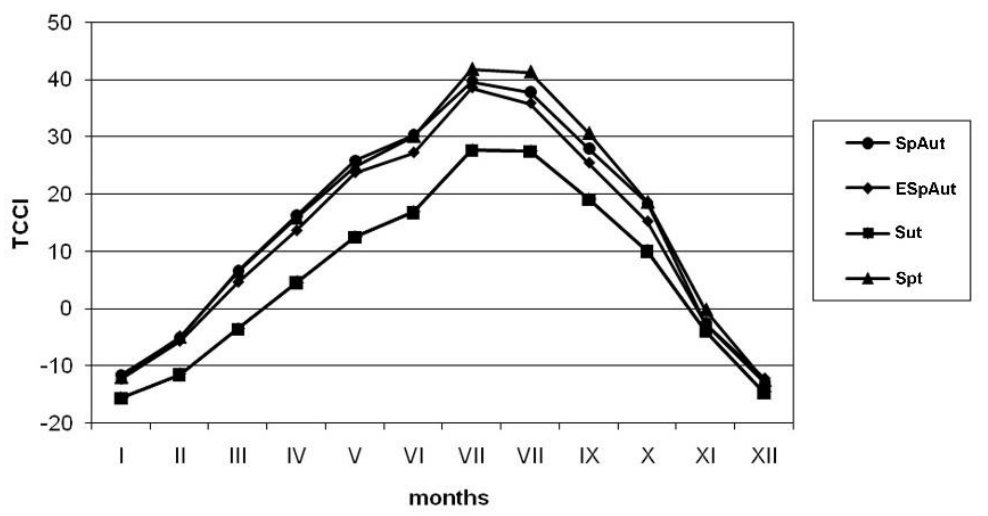

Figure 5. Four types of annual distribution of climate comfort zone in Serbia

The tourism climate comfort index was also analysed for the period 2001-2010, so as to point to the possible relation between the variability of $\mathrm{TCCl}$ and tourist visitation in the territory of Serbia. The warmest years in the analyzed period were 2007 and 2008, with the average temperatures of 11.8 and 
$11.7^{\circ} \mathrm{C}$ (http://www.hidmet.gov.rs). The analysis of the differences between this and the previous period leads to a conclusion that there was no significant redistribution of the stations according to comfort, but the index values noticeably "raised" for all the stations in all months.

A complex analysis of validity of the proposed TCCI model also includes an evaluation of its values in relation to the indicators of tourism turnover. It is clear that an indicator of tourism turnover is a component not exclusively defined by climate determinants, but also by tourism amenities (natural, anthropogenic and ambient values) that characterise the tourist identity of a destination.

An analysis of tourism turnover and TCCI depends on the seasonality of tourism turnover of a tourist destination. The examples of the most visited city, the most visited mountain resort and the most visited spa centre have been selected for analysis.
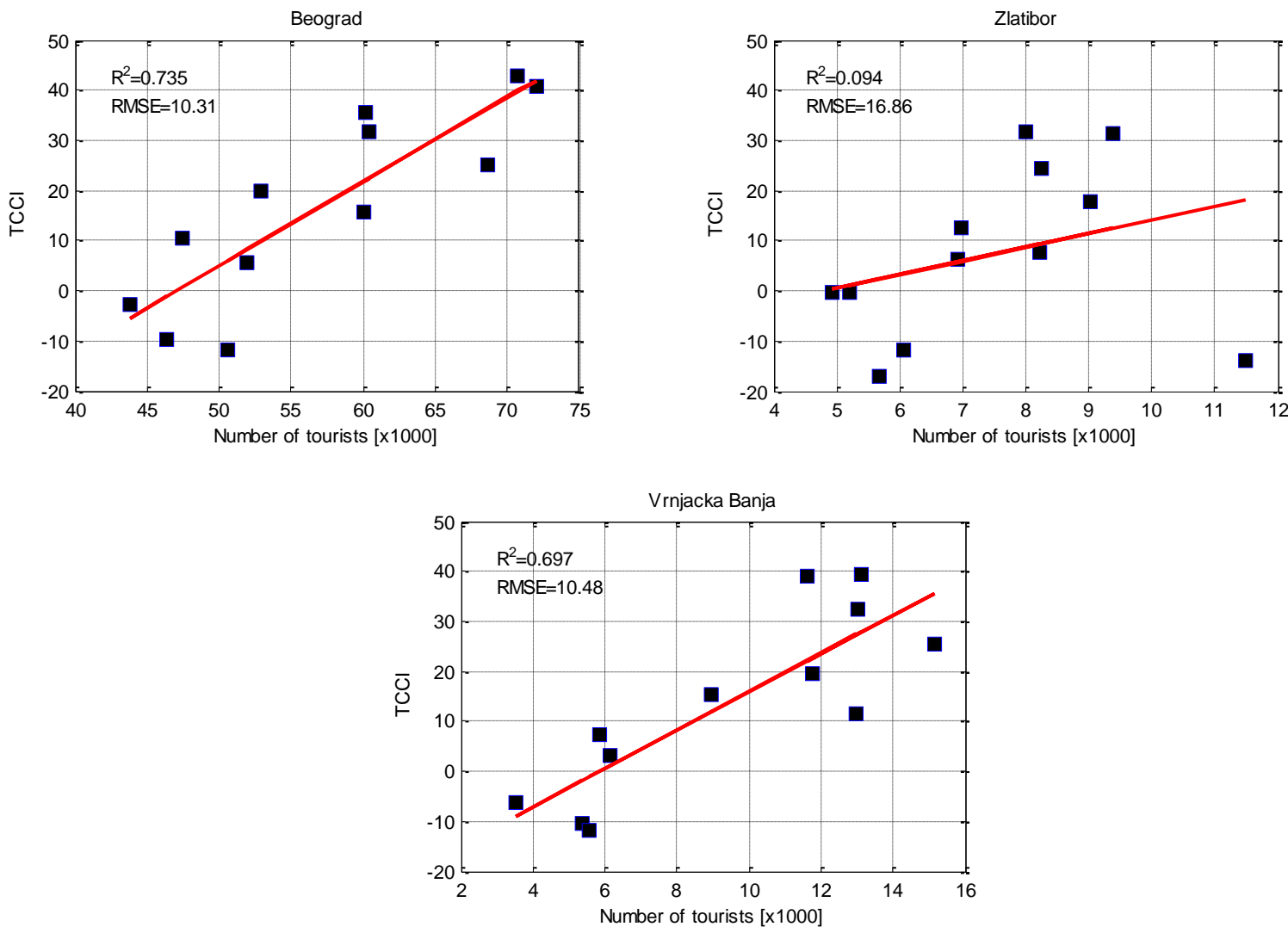

Figure 6. Linear regression graph for Beograd, Zlatibor and Vrnjačka Banja (relation between the number of tourists and TCCI)

Linear regression graph is shown evident relation between analysed parameters of TCCl and number of tourists for the examples of Beograd and Vrnjačka Banja. However, on the example of Zlatibor it is obvious significant point's dispersion around regression line. The determination coefficient $\left(R^{2}\right)$ in Figure 6 displays a low value for a destination with higher tourist turnover in winter than in summer, because the low value of $\mathrm{TCCl}$ is caused by low air temperature in winter and by snowy days that create favourable conditions for winter - snow activities. Values of $\mathrm{TCCl}$ in the warmer half of the year correspond to recreational activities, especially walking. Zlatibor is not only mountain tourist center, but also climatic place, so that on this mountain there are favorable conditions for health tourism. Zlatibor is profiled as a mountain suitable for rest, recuperation and treatment, that is already adequately utilized in management.

According to the official statistical data about number of tourist (http://webrzs.stat.gov.rs) for Belgrade, the major city-brake destination in the South-east part of the Europe, the most visited month is September and it corresponds with ideal value of TCCI (25.07). Zlatibor, a mountain in the west part of Serbia is in terms of tourism the most visited mountain centre in Serbia. The most of the tourist capacities 
(accommodation facilities and restaurants) were built at an altitude of about $1000 \mathrm{~m}$. On the example of Zlatibor, the average number of tourists observed for period 2001-2010 in January is 11,500 and for July is about 8,000 tourists, when the value of $\mathrm{TCCl}$ is the highest (http://webrzs.stat.gov.rs).

Entirely different results can be perceived at the example of one tourist centre where tourist turnover reaches its peak during summer. The maximum number of tourists was registered in May with over 15,000 (http://webrzs.stat.gov.rs) and that value coincides with almost ideal TCCI (25.32) calculated for the nearest meteorological station - Kraljevo $(215 \mathrm{~m}$ ). Linear regression graph (Figure 6) shows a very high degree of determination coefficient. Similar results were obtained in an analysis of the relation between the TCCl and tourism turnover in tourist centres of Montenegro (Joksimović et al., 2013).

On basis of the previous results and their consideration for the purpose of tourism activities, we think that the values presented in the scale of climate comfort according to the calculated values of climate index are correspondent to the sensation of comfort caused by air temperature (Table 1). In view of that, simple methods of reducing these indices to a daily level, e.g. by way of simple division by 30 as some authors have done for specific indices (Perch-Nielsen et al., 2010), or reducing to an annual level (Amelung and Viner, 2006), are not justified and they are a limitation to the applied methodology. A limited availability of statistical data on tourism visitation, which was possible to monitor in continuity only for the period 2001-2010, poses an evident limitation to much wider testing the set hypothesis. The TCCI doesn't consider parameters for wind because of in accordance with the spatial-temporal characteristics of climate on analyzed territory, the average wind speed as a parameter on a monthly basis has no significant values that would be reflected in the comfort of tourists. At the territory of Serbia the windiest meteorological station is Crni Vrh, with average values of wind speed above $6 \mathrm{~m} / \mathrm{s}$ (http://www.hidmet.gov.rs) which is minimal value with significant influence on human comfort (De Freitas et al., 2008). Wind is an important parameter in the selection of a holiday destination when it comes to extreme sports (surfing, sailing, paragliding), which are isolated phenomena in the tourist offer of mainland countries as Serbia is.

In a way, meteorological factors can function as a double-edged sword, with one edge promoting tourism activities and the other hindering them (Olya and Alipour, 2015b). The results of our research pointed to several important issues related to climate and tourism management: climatic suitability in different seasons, creating different activities for tourists (especially recreation), relation between climatic elements and human thermal comfort. The spatial-temporal pattern of the TCCI shows where tourists can experience adequate weather conditions at certain seasons. Such information has marketing implications for travel agencies. They can utilize the information to determine when the climate in Serbia is most likely to be suitable for outdoor and indoor activities.

\section{Conclusion}

In accordance with the starting point of the research that a climate parameter - air temperature is crucial for the sensation of comfort, the paper has presented one of the possible modifications of the classical $\mathrm{TCl}$ expressions. The research presented in this paper was aimed at forming TCCl whose values would correspond to the values that a large number of users are familiar with, such as air temperature. Statistical examination of the set correlation between a large number of climate parameters and on basis of the data from 26 meteorological stations on the territory of Serbia led to a TCCI value scale correspondent to air temperature values. As the comparison with the indicator of tourism visitation (number of tourists) indicated a high degree of determination, the set hypothesis and the aim of the study have proven justified.

This paper presents an attempt to formulate an index quantity appropriate to be used not only in tourism, but also in bioclimatology, tourism management, planning and improvement of spatial development. The proposed methodology of calculating $\mathrm{TCCl}$ can be an initial direction to further research that will take into account the necessary modifications due to the climate changes in different geographic positions. Implementation of geostatistical method CoKriging provides values of TCCI for the whole Serbian territory, 
also taking into account an altitude. According to the size of Serbian territory, further studies might involve a considerably larger and wider area taking into consideration the actual scenarios of climate changes with respect to regional variations.

The main advantages of climate indexes as TCCl are that they provide an easy, quick, objective view of the relationship between climate conditions and tourism attractiveness. Additionally, they can be adapted to different market segments with specific climatic preferences. Optimal application of this index in moderate climatic zones, where the high frequency of extreme climatic phenomena are not expressed. Information about climate in tourist destinations in Serbia are rather general. The results of climate indices and their marketing contribute to choosing the most appropriate destinations for a certain type of climate treatment or recreation.

Although many important attributes such as climate are outside the control of tourism practitioners and policy makers, they can nevertheless utilize their knowledge of demand patterns and develop their marketing plans and tourism resources accordingly.

\section{Acknowledgements}

We are grateful to the reviewers for their very helpful suggestions and comments which lead to the improvement of our paper. Part of this work is included in a projects No. 176008 and No. 176017, financed by the Ministry of Education, Science and Technological Development of the Republic of Serbia.

\section{References}

Amelung B. and Viner D. (2006), Mediterranean Tourism: Exploring the Future with the Tourism Climatic Index, Journal of Sustainable Tourism, 14(4), 349-366.

Becker S. (1998), Beach Comfort Index - a new approach to evaluate the thermal conditions of beach holiday resorts using a South African example, Geojournal, 44(4), 297-307.

Becker S. (2000), Bioclimatological rating of cities and resorts in South Africa according to the climate index, International Journal of Climatology, 20(12), 1403-1414.

Besancenot J.P. (1989), Climat et tourisme, Masson, Paris.

Bigano A., Hamilton J.M. and Tol R.S.J. (2006), The impact of climate on holiday destination choice, Climatic Change, 76(3-4), 389-406.

De Freitas C. (1990), Recreation climate assessment, International Journal of Climatology, 10(1), 89-103.

De Freitas C. (2003), Tourism climatology: Evaluating environmental information for decision making and business planning in the recreation and tourism sector, International Journal of Biometeorology, 48(1), 45-54.

De Freitas C.R., Scott D. and McBoyle G. (2008), A second generation climate index for tourism (CIT): specification and verification, International Journal of Biometeorology, 52(5), 399-407.

Eugenio-Martin J.L. and Campos-Soria J.A. (2010), Climate in the region of origin and destination choice in outbound tourism demand, Tourism Management, 31(6), 744-753.

Førland J.E., Jacobsen J.S., Denstadli J.M., Lohmann M., Hanssen-Bauer I., Hygen H.O. and Tømmervik H. (2013), Cool weather tourism under global warming: Comparing Arctic summer tourists' weather preferences with regional climate statistics and projections, Tourism Management, 36, 567-579.

Goh C. (2012), Exploring Impact of Climate on Tourism Demand, Annals of Tourism Research, 39(4), 1859-1883.

Gómez Martín Ma B. (2005), Weather, Climate and Tourism - A Geographical Perspective, Annals of Tourism Research, 32(3), 571-591.

Jacobsen J.K.S., Denstadli J.M., Lohmann M. and Førland E.J. (2011), Tourist weather preferences in Europe's Arctic, Climate Research, 50(1), 31-42.

Joksimović M., Gajić M. and Golić R. (2013), Tourism climatic index in the valorisation of climate in tourist centers of Montenegro, Bulletin of the Serbian Geographical Society, 93(1), 15-34. (In Serbian)

Matzarakis A. and Nastos P. (2011), Analysis of Tourism Potential for Crete Island, Greece, Global NEST Journal, 13(2), 141-149. 
Matzarakis A., Endler C. and Nastos P.T (2014), Quantification of Climate-Tourism Potential For Athens, Greece Recent And Future Climate Simulations, Global NEST Journal, 16(1), 43-51.

Meze-Hausken E. (2007), Grasping climate perceptions as an issue of measuring climate impacts on society, International Journal of Biometeorology, 52(1), 1-2.

Meze-Hausken E. (2008), On the (im-)possibilities of defining human climate thresholds, Climatic Change, 89(3-4), 299-324.

Mieczkowski Z. (1985), The tourism climatic index: A method of evaluating world climates for tourism, Canadian Geographer, 29(3), 220-233.

Moreno A., Amelung B. and Santamarta L. (2008), Linking beach recreation to weather conditions. A case study in Zandvoort, Netherlands, Tourism in Marine Environments, 5(2-3), 111-119.

Morgan R., Gatell E., Junyent R., Micallef A., Özhan E. and Williams A. (2000), An improved user-based beach climate index, Journal of Coastal Conservation, 6(1), 41-50.

Olya H. and Alipour H. (2015a), Modeling tourism climate indices through fuzzy logic, Climate Research, 66(1), 49-63.

Olya H.G.T. and Alipour H. (2015b), Risk assessment of precipitation and the tourism climate index, Tourism Management, 50, 73-80.

Perch-Nielsen S., Amelung B. and Knutti R. (2010), Future climate resources for tourism in Europe based on the daily Tourism Climatic Index, Climatic Change, 103, 363-381.

Republic Hydrometeorological Service of Serbia, from http://www.hidmet.gov.rs

Rosselló-Nadal J. (2014), How to evaluate the effects of climate change on tourism, Tourism Management, 42, 334-340.

Scott D., Gössling S. and de Freitas C.R. (2007), Climate Preferences for Tourism: an Exploratory Tri-Nation Comparison, In: Developments in Tourism Climatology, Matzarakis A., de Freitas C. and Scott D. (Eds.), 3rd International Workshop on Climate, Tourism and Recreation, Alexandroupolis, Greece.

Scott D., Gössling S. and de Freitas C.R. (2008), Preferred climates for tourism: case studies from Canada, New Zealand and Sweden, Climate Research, 38(1), 61-73.

Statistical Office of the Republic of Serbia, from http://webrzs.stat.gov.rs

Tang M. (2013), Comparing the 'Tourism Climate Index' and 'Holiday Climate Index' in Major European Urban Destinations, Master Thesis, University of Waterloo, Canada.

Vitt R., Gulyás A. and Matzarakis A. (2015). Temporal Differences of Urban-Rural Human Biometeorological Factors for Planning and Tourism in Szeged, Hungary. Advances in Meteorology, Volume 2015. http://dx.doi.org/10.1155/2015/987576 